\title{
On extreme atmospheric and marine nitrogen fluxes and chlorophyll-a levels in the Kattegat Strait
}

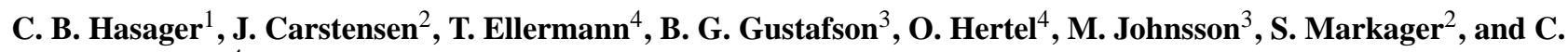 \\ Ambelas Skjøth ${ }^{4}$ \\ ${ }^{1}$ Risø National Laboratory, Wind Energy Dept. Roskilde, Denmark \\ ${ }^{2}$ National Environmental Research Institute, Marine Ecology, Roskilde, Denmark \\ ${ }^{3}$ Gothenburg University, Oceanography Dept., Gothenburg, Sweden \\ ${ }^{4}$ National Environmental Research Institute, Atmospheric Environment, Roskilde, Denmark
}

Received: 6 February 2003 - Published in Atmos. Chem. Phys. Discuss.: 27 March 2003

Revised: 16 June 2003 - Accepted: 17 June 2003 - Published: 19 June 2003

\begin{abstract}
A retrospective analysis is carried out to investigate the importance of the vertical fluxes of nitrogen to the marine sea surface layer in which high chlorophyll a levels may cause blooms of harmful algae and subsequent turn over and oxygen depletion at the bottom of the sea. Typically nitrogen is the limiting factor for phytoplankton in the Kattegat Strait during summer periods (May to August) and the major nitrogen inputs come from the atmosphere and deepwater entrainment. The extreme reoccurrence values of nitrogen from atmospheric wet and dry deposition and deep-water flux entrainments are calculated by the periodic maximum method and the results are successfully compared to a map of chlorophyll return periods based on in-situ observations. The one-year return of extreme atmospheric wet deposition is around $60 \mathrm{mg} \mathrm{N} \mathrm{m}^{-2} \mathrm{day}^{-1}$ and $30 \mathrm{mg} \mathrm{N} \mathrm{m}^{-2}$ day $^{-1}$ for deep-water entrainment. Atmospheric nitrogen dry deposition is insignificant in the context of algal blooms. At longer time-scales e.g. at 10-year return, the nitrogen deep-water entrainment is larger than the extreme of atmospheric wet deposition. This indicates that the pool of nitrogen released from the sea bottom by deep-water entrainment forced by high winds greatly exceeds the atmospheric pool of nitrogen washed out by precipitation. At the frontal zone of the Kattegat Strait and Skagerrak, the nitrogen deep-water entrainment is very high and this explains the high 10-year return chlorophyll level at $8 \mathrm{mg} \mathrm{m}^{-3}$ in the Kattegat Strait. In the southern part, the extreme chlorophyll level is only $4 \mathrm{mg} \mathrm{m}^{-3}$ according to the statistics of a multi-year time-series of water samples. The chlorophyll level varies greatly in time and space as documented by a series of SeaWiFS satellite maps (OC4v4 algorithm) of chlorophyll ScanFish and buoy observations from an experimental period in the Kattegat Strait. It is recommended to sample in-situ chlorophyll observation
\end{abstract}

Correspondence to: C. B. Hasager

(charlotte.hasager@risoe.dk) collocated in time to the satellite overpasses of e.g. SeaWiFS and ENVISAT MERIS to ensure improved mapping of the chlorophyll levels in the Danish waters.

\section{Introduction}

The colour of the ocean is mainly influenced by phytoplankton that is very small single-celled plants. The plants contain green pigment called chlorophyll used to capture energy from the sunlight. In the Kattegat Strait one bloom of toxic algae (Chrysochomulina polylepis) has been reported from satellite Earth Observation (EO) data (Johannessen et al 1989, Dundas et al, 1989, Hansen et al, 1993). Coupling links between the atmospheric and marine environments are of importance when describing the physical and chemical processes giving rise to variations in chlorophyll-a $\left(C_{a}\right)$ concentration levels and algal blooms. Nitrogen is a basic nutrient for phytoplankton and often the limiting growth factor in spring and summer in coastal waters such as the Kattegat Strait (Granéli, 1987; Kronvang et al. 1993). Therefore the transport processes on nitrogen to and within the marine ecosystem are of interest for estimating the likelihood (risk) of encountering extremely high $C_{a}$ levels and (harmful) algal blooms. It is well known that nitrogen may be transported to the marine surface layer from three major sources: 1) riverine output, 2) up-welling from the bottom sea layer and 3) atmospheric deposition.

The focus of the study is on describing the links between the atmosphere and the marine environments during the algae growth season when the sea surface layer is depleted of nutrients. During spring and summer the riverine input is relatively small, hence the atmospheric deposition may be of significance. The vertical transport of nutrients to the surface mixed layer is strongly coupled to atmospheric processes in 
two ways, one is atmospheric wet and dry deposition, the other is wind-induced up-welling from the deep sea layer.

In a retrospective analysis, the occurrence of high $C_{a}$ levels and algal blooms in the Kattegat Strait have been investigated based on $C_{a}$ in-situ observations and compared to atmospheric and hydro dynamical measurements and model results on the vertical transport of nitrogen to the sea surface layer. Observations and model results covering more than a decade are included in the analysis and the result of the analysis is a quantification of the extreme values of the vertical fluxes of nitrogen to the sea surface layer. The goal of the analysis is to provide a better understanding of possible cause- effect relations in the marine environment.

A second part of the study investigates the spatial variations in $C_{a}$ in the Kattegat Strait from a short experimental period during which in-situ $C_{a}$ observations based on fluorescence are available from either a buoy or a moving ship. The results are compared to satellite-based maps of $C_{a}$ from SeaWiFS. The case study description is included to underline the great variability in space and time of $C_{a}$ in the Kattegat Strait. Mapping techniques for $C_{a}$ is described in some detail and discussed with the aim to recommend future monitoring initiatives such that more detailed analysis of the links in space and time between nitrogen inputs from the atmosphere and deep-water entrainment and high $C_{a}$ levels are facilitated.

The paper gives a brief presentation of the Kattegat Strait, then followed by a description of the methodology on $C_{a}$ mapping from satellite EO data (especially from the SeaWiFS sensor). The periodical maximum theory used for analysis of extreme events is described and the results on atmospheric and deep-water nitrogen fluxes extreme events are presented and discussed in context with the spatial map on extreme $C_{a}$ occurrences derived from in-situ $C_{a}$ observations. Comparison results between SeaWiFS and in-situ fluorescence observations on $C_{a}$ are presented and discussed.

\section{The Kattegat Strait}

The Kattegat Strait in the Scandinavian region is the marine water between Denmark and Sweden. It covers an area of $22.000 \mathrm{~km}^{2}$ centred at latitude $57^{\circ} 00^{\prime}$ and longitude $11^{\circ} 30^{\prime}$ (Fig. 1). The water depths vary down to $100 \mathrm{~m}$ and the eastern part is much deeper than the western part (Fig. 1 and 7). Water feeds into Kattegat from Skagerrak in the North and from the Baltic Sea though the Belts and the Sound from the South. Kattegat is normally considered well-mixed down to $10-15 \mathrm{~m}$ below the surface, where a salinity gradient separates the less saline water originating from the Baltic Sea from the more saline water originating from the Skagerrak. During winter and spring a significant amount of nitrogen is contributed from land-based run-off through small rivers. Typically this results in spring blooms. In the summer period nutrients are depleted from the upper well-mixed zone
(Richardson 1996). The Kattegat Strait is eutrophic i.e. socalled case 2 water. In the current study, the focus is on the likelihood that atmospheric nitrogen deposition may cause high $C_{a}$ and algal blooms. Hence in order to avoid analysing the cases of high $C_{a}$ level mainly fuelled by out washed nitrogen from streams, only the late spring and summer period is investigated. In summer run-off from land is minimal. The inter-annual levels in total atmospheric $\mathrm{N}$ deposition to the Kattegat Strait in the years 1996-1999 are found to vary 65\% (Ambelas Skjøth et al. 2002). In a previous study it has been shown that the flux of nitrogen during atmospheric deposition events is in the range of $20-25 \mathrm{mg} \mathrm{N} \mathrm{m}^{-2}$ day $^{-1}$ (Asman et al., 1995). Using the Redfield ratio for phytoplankton composition this corresponds to an additional primary production of $114-284 \mathrm{mg} \mathrm{C} \mathrm{m}^{-2} \mathrm{day}^{-1}$. Comparing this range to the average primary production in Kattegat, it is found that an atmospheric deposition event could contribute approximately $50 \%$ of the average primary production.

An input of $70 \mathrm{mg} \mathrm{N} \mathrm{m}^{2} \mathrm{day}^{-1}$ to mesocosm experiments show an increase of $C_{a}$ of $20 \%$ in waters from the Kattegat Sea. The experiment was part of the MEAD (see acknowledgements) project. This amount of nitrogen will have to be added to the surface water during a period of say one to three days.

\section{Chlorophyll-a mapping}

The chlorophyll level may either be measured through electromagnetic reflectivity by remote sensors, through fluorescence by fluorometers or water samples analysed by HPLC in the laboratory. The two latter methods are in-situ observations taken within the water column, whereas the remote sensors typically are mounted on spacecrafts, airplanes or platforms. High $C_{a}$ levels and algal blooms may occur at a time scale from a few days up to weeks and the spatial distribution is highly variable. Typical growth rates of phytoplankton are a doubling in about a day. The different mapping techniques on $C_{a}$ are described to provide an overview of techniques currently available.

\subsection{Satellite Earth Observation data}

Frequent, instantaneous spatial mapping of $C_{a}$ is only feasible from satellite EO. The technology on mapping $C_{a}$ from satellite EO data dates back to the late 1970'ties (e.g. Stewart, 1985) when the Coastal Zone Color Scanner (CZCS) sensor was flown on-board the satellite NIMBUS-7 from 1978 to 1986 for NASA, USA (Kramer, 1996). A detailed study of CZCS observations of the Danish coastal waters showed that the yellow substance significantly influence the water leaving radiances. It was concluded that more optical channels, than available at CZCS, would be needed to obtain algorithms suitable for case 2 water masses as compared to case 1 (oligotrophic) waters (Joergensen, 1999). Eight 


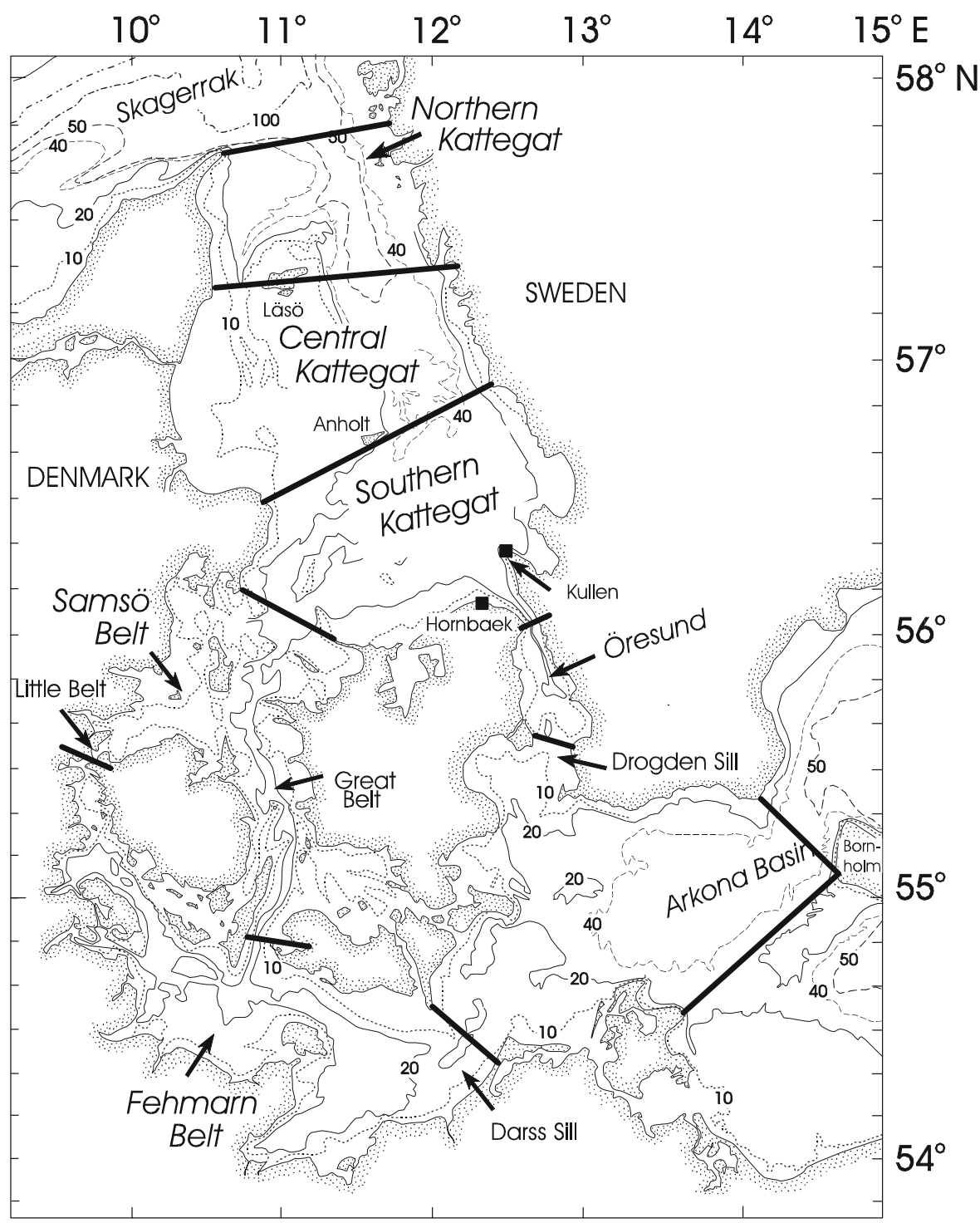

Fig. 1. Map of the Kattegat Strait showing the three sub-basin: Northern, Central and Southern Kattegat. Water depth is shown as isocurves in meters.

months of EO ocean colour data are available in 1996 to 1997 from OCTS (Ocean Colour and Temperature Sensor) from NASDA, Japan and POLDER (Polarization and Directionality of the Earth's Reflectance's) from CNES, France both on-board the ADEOS-1 satellite.

However, only since SeaWiFS (Sea-viewing Wide Fieldof-view Sensor) on-board the satellite SeaStar started operation for NASA, USA in September 1997, does a multi-year global coverage EO data archive exist for ocean colour mapping. In the intervening period between CZCS and SeaWiFS several investigators have analysed NOAA AVHRR (daily data archive from 1979) and Landsat TM (bi-monthly data archive from 1982) in regard to $C_{a}$ levels. The results obtained are crude estimates, e.g. Svejkovsky and Shandley
(2001) note that AVHRR's apparent lower detection limit on plankton concentrations is $2-3 \mathrm{mg} \mathrm{m}^{-3}$ on $C_{a}$. This corresponds approximately to human visual separation of "clear" and "dirty" water. The technique is based on reflectivity. Another method based on sea surface temperature (SST) anomalies e.g. Johannessen et al. (1989), is only able to delineate the algal plume spreading through time rather than estimate the $C_{a}$ concentration.

Society's wish for EO ocean colour observations has been high and currently ten EO satellite sensors are in orbit mapping ocean colour. See IOCCG (International Ocean Colour Coordinating Group, http://www.ioccg.org/sensors/ $500 \mathrm{~m} . h \mathrm{tml}$ 2) for a list of platforms, instruments and sensor characteristics. Near-real time operational mapping of 
$C_{a}$ based on SeaWiFS is undertaken for the North Sea, Skagerrak and Norwegian coast, see http://www.nrsc.no/ HAB/browser/2001.htm. The domain also covers the Kattegat Strait.

Five SeaWiFS scenes are analysed in the current study. The requirement from NASA on $C_{a}$ level is an accuracy of $35 \%$ but this has been difficult to fully meet with the OC2 algorithm especially in case 2 water (O'Reilley et al., 1998). The newest operational algorithm, OC4v4 (O'Reilley et al., 2002) seems to be able to meet the accuracy of $35 \%$ for case 1 and case 2 waters. The algorithm is based on 4 channels whereas the OC2 algorithm is based on only two channels. The OC $4 v 4$ algorithm is

$C_{a}=10.0^{0.366-3.067 R_{4}+1.930 R_{4}^{2}+1.532 R_{4}^{4}}$

where

$R_{4}=\log _{10}\left(R_{555}^{443}>R_{555}^{490}>R_{555}^{510}\right)$.

$C_{a}$ is the chlorophyll a concentration $\left(\mathrm{mg} \mathrm{m}^{-3}\right) . R_{4}$ is the reflectance determined from four optical bands. The bands are $20 \mathrm{~nm}$ wide and are centered at the four wavelength, $\lambda$, at $443 \mathrm{~nm}$ (blue), $490 \mathrm{~nm}$ (blue-green), $510 \mathrm{~nm}$ (green) and $555 \mathrm{~nm}$ (green) and is the reflectance band ratio between the wavelength, $\lambda_{1}$ and $\lambda_{2}$. The band ratio $R_{555}^{490}$ is the best overall single band ratio index on $C_{a}$ concentration, but because $R_{555}^{443}$ is superior in oligotrophic waters and $R_{555}^{510}$ is superior in eutrophic water, the so-called maximum band ratio is used in the polynomial function (Eq. 1). In other words, the OC4v4 algorithm takes advantage of the band-related shift in precision that is a function of the well-known shift of the maximum $R(\lambda)$ spectra towards higher wavelengths with increasing $C_{a}$ (O'Reilley et al., 2002). Recently, Joergensen (2003) has successfully compared SeaWiFS OC $4 v 4 C_{a}$ data to $C_{a}$ in-situ observations for a limited data set consisting of 30 match-up's in the Danish waters.

\subsection{In-situ techniques}

Three types of in-situ $C_{a}$ observations are available in the current study. One is classical water samples (HPLC), the others are fluorescence measurements from a buoy and a moving ship. The SeaWiFS scenes are selected from days where either the buoy or the ship data on $C_{a}$ are available.

The water sampling technique is based on point observations at various water depths. The $C_{a}$ concentration is analysed in the laboratory with HPLC technique known to have an error of $7 \%$ in duplex tests but up to $50 \%$ in case of inhomogeneous water (pers. com. B. Pedersen). In-situ $C_{a}$ water samples were collected by the Danish and Swedish monitoring authorities. In Denmark, the National Environmental Institute (NERI) and the counties perform the monitoring and in Sweden, the Swedish Meteorological and Hydrological Institute (SMHI). The combined dataset covers more than ten years of observations collected at 50 stations. See Fig. 5 for the position of the sampling stations. The observations from the upper $10 \mathrm{~m}$ are averaged to represent the sea surface layer.

Buoy observations of $C_{a}$ are retrieved from a flourometer. The buoy was moored in the Kattegat Strait at latitude $57.1818^{\circ} \mathrm{N}$, longitude $11.5313^{\circ} \mathrm{E}$ (Fig. 7). Hourly observations of $C_{a}$ at $-2 \mathrm{~m}$ depth were collected during an experimental period. The accuracy on $C_{a}$ is known to be best during night time when daylight is not acting as excitation light source in combination with the instrument light source.

ScanFish observations of $C_{a}$ were obtained during several experimental cruises. The ScanFish is an undulating wing dragged after a ship. The ScanFish data are retrieved by a flourometer (WETLABS, WETStar Miniature Fluorometer) and the fluorescence detected is calculated into $C_{a}$ from the following relationship

$F l=2.439 C_{a}-2.143$

with $F l$ fluorescence $\left(\mathrm{mg} \mathrm{m}^{-3}\right)$ and $C_{a}\left(\mathrm{mg} \mathrm{m}^{-3}\right)$.

The $C_{a}$ levels are recorded in transects up to $32 \mathrm{~km}$ long and down to $70 \mathrm{~m}$ water depth (Johnsson, 2002). In the current study however, only the surface layer is investigated and $C_{a}$ is averaged over the top $5 \mathrm{~m}$ of the surface layer. Figure 7 shows the ship tracks for the period in early June 2001 from which a SeaWiFS scene was analysed.

\section{Theory on extreme events}

The theory used to assess the extreme events of atmospheric deposition and nutrient fluxes from the bottom of sea is the periodical maximum method.

The method is based on dividing the record of observations into $\mathrm{n}$ periods of equal length, here one year. The record of extreme observations $\left(X_{i}^{\max }\right)$ per year is sorted in ascending order, and it has been shown that if the tail of the distribution of observations is exponential, then the extreme observations have (asymptotically) an accumulated probability which is double exponential (Gumbel, 1958; Mann et al. 1998)

$F(X)=\exp (-\exp (-\alpha(X-\beta)))$.

The parameters $\alpha$ and $\beta$ are extracted following Abild (1994)

$b=\frac{1}{n} \sum_{i=n}^{n} \frac{i-1}{n-1} X_{i}^{\max }$

and

$\alpha=\frac{\ln 2}{2 b-\overline{X^{\max }}}, \quad \beta=\overline{X^{\max }}-\frac{\gamma}{\alpha}$

where $\gamma$ is Euler's constant $\approx 0.577216$ and $\overline{X^{\max }}$ is the mean of the maximum values.

The reoccurrence interval is $T$ and the corresponding maximum value $X_{T}$ is calculated from

$X_{T}=\frac{\ln T}{\alpha}+\beta$. 
To check that the time-series is described well be the Gumbel probability distribution, plots of $F(X)$ are compared with a simple theoretical expression $P \sim(i-0.5) / n$ (S. Ott, pers. comm.).

\section{Extreme events of nitrogen fluxes to the Kattegat Strait}

Extreme events of nitrogen fluxes to the Kattegat Strait from the atmosphere and from deep-water entrainment are described in Sect. 5.1 and 5.2, respectively. The occurrence of extreme chlorophyll-a levels in the Kattegat Strait is described in Sect. 5.3 and a case study showing the variability in time and space of chlorophyll-a is presented in Sect. 5.4. The case study is included to demonstrate the high variability in $C_{a}$ in the Kattegat Strait. The case study also indicates that spatial sampling of $C_{a}$ could be improved in future monitoring. The combination of results from these four sections is discussed in Sect. 6.

In summary, the investigation is based on observations of

- atmospheric wet deposition from Anholt (bi-monthly for 13 years)

- atmospheric wet deposition from Tange (daily for 8 years)

- atmospheric dry deposition for the sea near Anholt (daily for 12 years)

- atmospheric wet and dry deposition from three grid cells in the Kattegat (daily for 1 year)

- deep-water nitrogen fluxes from three sub-basins in the Kattegat (daily for 25 years)

- $C_{a}$ in-situ observations from 50 stations in the Kattegat (per three weeks or less for 10 years)

- $C_{a}$ satellite observations (instantaneous at 6 days, case study)

- $C_{a}$ in-situ buoy observations (30 minute values for 2 months, case study)

- $C_{a}$ in-situ Scan-Fish (ship tracks during one day, case study)

The measurement techniques used to monitor nitrogen wet deposition is either "open" or "closed" systems. The "closed" system is a wet-only sampling system. Daily wet deposition sampling with a "closed" system means that the sampler is only open during precipitation events and otherwise closed, whereas the bi-monthly sampling system is always open (Ellermann et al., 1996). It is beyond the current study to go into detail with general differences in the two sampling systems, however just note that the "closed" system collects less total nitrogen as very small precipitation events

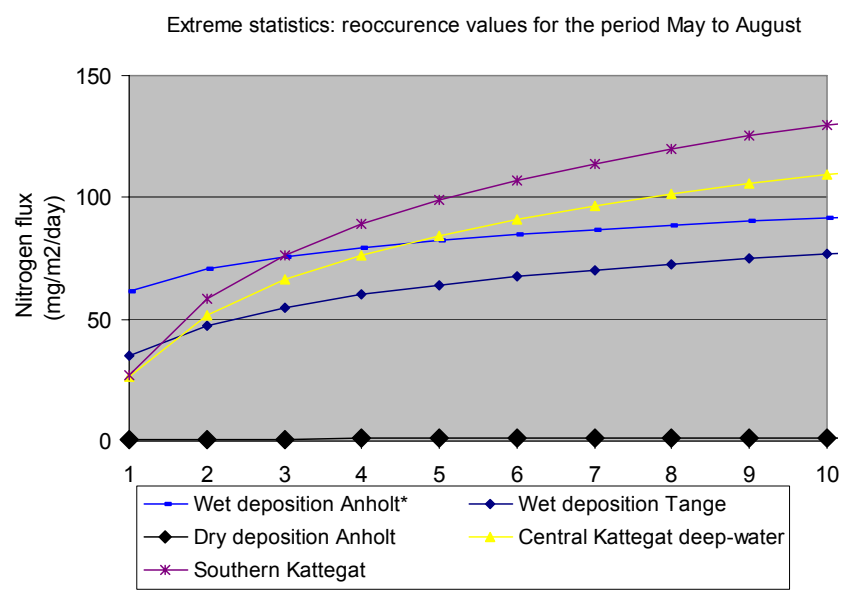

Fig. 2. Return periods of nitrogen input in the summer periods May to August to the surface layer water in the Kattegat Strait from the atmosphere as wet and dry deposition and estimated from a hydro dynamical model dividing the basin into three sub-basins. The wet deposition of nitrogen in Tange is based on daily observations. The dry deposition of nitrogen is based on daily concentration measurements at Anholt and meteorological observations from Beldringe.*NOTE: The wet deposition of nitrogen at Anholt are based on bi-monthly observations.

will not be logged with the "closed" system but only with the "open" system. The open system also collects an (unknown) amount of dry deposition.

\subsection{Atmospheric deposition}

Transport of atmospheric nitrogen to the surface takes place through both dry and wet deposition. Two groups of nitrogen compounds contribute to the deposition - ammonia and particulate ammonium, and gas phase as well as particulate phase nitrogen oxides. Ammonia is mainly emitted from agricultural activities and reacts in the atmosphere with acid gas phase or aerosol phase compounds to form particulate ammonium. Nitrogen oxides are emitted as nitrogen monoxide and nitrogen dioxide from combustion processes e.g. traffic, industry and power production. Nitrogen oxides take place in a number of photo chemically initiated reactions in the atmosphere and from particulate nitrate.

Ammonia is relatively quickly dry deposited, but this removal competes with the transformation into aerosol phase ammonium since also the chemical conversion is fast. The concentration of ammonia therefore decreases relatively fast when moving from an emission area. Nitrogen dioxide dry deposit to plant surfaces but the solubility is very low for both nitrogen dioxide and nitrogen monoxide. For the later, the dry deposition is insignificant. Dry deposition of nitrogen oxides is therefore mainly from nitric acid which forms from nitrogen dioxide by approximately $5 \%$ per hour. Nitric acid is, however, also quickly converted into aerosol phase nitrate. 

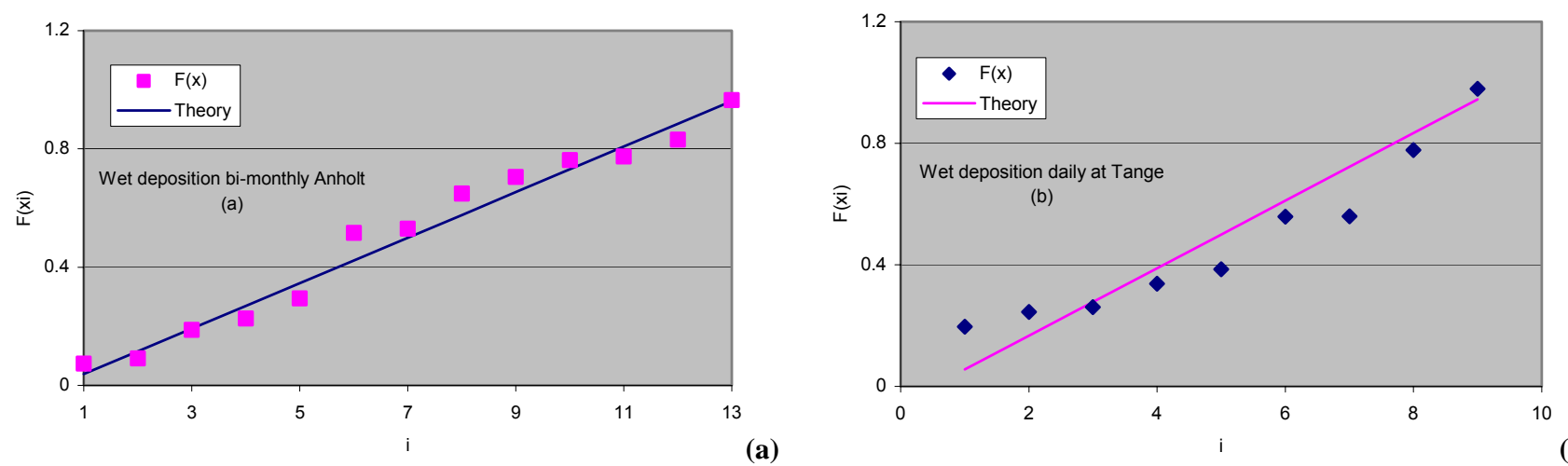

(b)
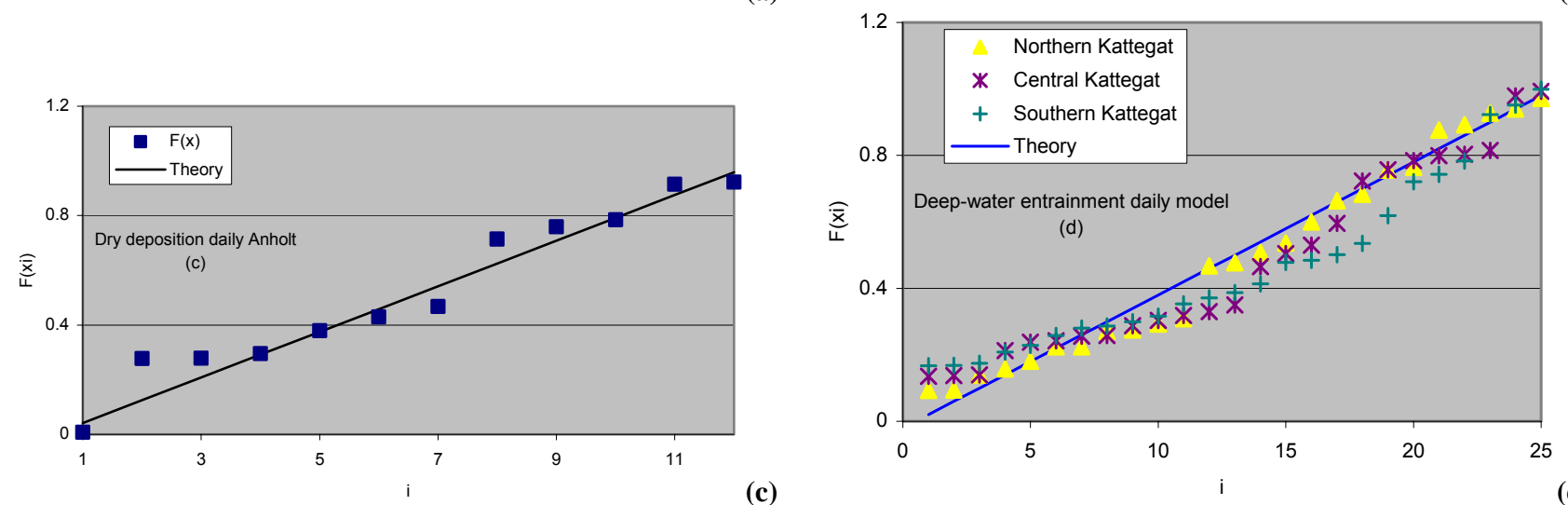

(d)

Fig. 3. Check on the extreme tail of observations $(F(x))$ to follow the Gumbel probability function (theory line) for the period 1 May to 31 August: (a) atmospheric nitrogen wet deposition at Anholt (1989-2001); (b) atmospheric nitrogen wet deposition at Tange (1989-1997); c) nitrogen dry deposition at Anholt (1990-2001); (d) deep-water nitrogen fluxes calculated by a hydrodynamic model (1976-1999) for three sub-basins in the Kattegat Strait. (Results for the full year are similar but not shown.)

The main part of the atmospheric nitrogen deposition to marine waters arises from wet deposition of aerosol phase nitrate and ammonium. These compounds are associated with aerosol. As these hardly dry deposit (lifetime with respect to dry deposition is in the order of a week), the main removal path is wet deposition.

Wet depositions of ammonium and nitrate are monitored on the island Anholt in the middle of the Kattegat Strait on bimonthly intervals within the Danish Background Monitoring Program (Ellermann et al., 2002) and observations from 1989 to 2001 are analyzed in the current study. A complimentary analysis based on daily wet deposition observations from a rural site in Jutland is given in order to estimate the extreme deposition on a daily time scale.

Measurements of dry deposition fluxes is highly resource demanding. Dry depositions are therefore estimated from measured atmospheric concentrations and computed dry deposition velocities (Ellermann et al., 1996). The daily dry deposition rate to the sea near Anholt is calculated based on meteorological observations in Beldringe and the results from 1990 to 2001 are analysed in the current study. The island Anholt is located in the centre of the sea, hence the observations are assumed to be representative for the whole Kattegat Strait.

Results from the ACDEP model (http://www.dmu.dk/ AtmosphericEnvironment/ACDEP/, Hertel, 1995) on wet and dry deposition are available at a daily interval with a grid resolution of $30 \mathrm{~km}$ by $30 \mathrm{~km}$ from one year (year 2001) (Ellermann, 2002). The time-serie is used to assess the spatial variability on atmospheric deposition and to estimate the variation in wet deposition at a daily time scale compared to the bi-monthly observations.

Marine nitrogen flux data at a daily time-scale (19761999) are retrieved from a hydrodynamic model (see Sect. 5.2 for details) and the in-situ $C_{a}$ observations during 10 years are described in Sect. 5.3. Section 5.4 deals with the case study on $C_{a}$ from satellite, in-situ buoy and ScanFish data.

\subsubsection{Wet deposition}

In order to estimate extreme events on nitrogen wetdeposition to the Kattegat Strait, ammonium and nitrate have been summed. The average summed wet deposition is $32 \mathrm{mg} \mathrm{N} \mathrm{m}^{-2}$ bi-monthly ${ }^{-1}$ and the maximum is 
Table 1. Extreme events at one, ten and hundred year reoccurrence for atmospheric nitrogen wet deposition at bi-monthly values (Anholt) and daily values (Tange, in bold italic), nitrogen dry deposition daily values at Anholt and daily deep-water nitrogen flux calculated from a hydrodynamic model for three sub-basins. Values for summer periods (May to August) and the full year

\begin{tabular}{|c|c|c|c|c|c|c|}
\hline & \multirow[b]{2}{*}{$\begin{array}{l}\text { Return period } \\
\text { (years) }\end{array}$} & \multicolumn{2}{|c|}{$\begin{array}{l}\text { Atmospheric nitrogen } \\
\text { deposition (Anholt) }\end{array}$} & \multicolumn{3}{|c|}{$\begin{array}{l}\text { Deep-water nitrogen entrainment } \\
\text { in three Kattegat Strait sub-basins }\end{array}$} \\
\hline & & $\begin{array}{c}\text { wet } \\
\mathrm{mg} \mathrm{N} \mathrm{m}^{-2} \text { day }^{-1}\end{array}$ & $\mathrm{mg} \mathrm{N} \mathrm{m}^{-2}$ day $^{-1}$ & $\begin{array}{c}\text { North } \\
\operatorname{mg~N~m}^{-2} \text { day }^{-1}\end{array}$ & $\begin{array}{c}\text { Central } \\
\mathrm{mg} \mathrm{N} \mathrm{m}^{-2} \text { day }^{-1}\end{array}$ & $\begin{array}{c}\text { South } \\
\mathrm{mg} \mathrm{N} \mathrm{m}^{-2} \text { day }^{-1}\end{array}$ \\
\hline \multirow[t]{3}{*}{ Summer } & 1 & $62^{*}(32)$ & 0.7 & 173 & 27 & 27 \\
\hline & 10 & $92 *(76)$ & 1.1 & 620 & 109 & 130 \\
\hline & 100 & $121^{*}(\mathbf{1 2 0})$ & 1.5 & 1068 & 192 & 232 \\
\hline \multirow[t]{3}{*}{ Year } & 1 & $69 *(35)$ & 0.9 & 771 & 114 & 164 \\
\hline & 10 & $106^{*}(77)$ & 1.5 & 1917 & 256 & 381 \\
\hline & 100 & $143^{*}$ (118) & 2.1 & 3063 & 398 & 597 \\
\hline
\end{tabular}

* the values are in $\mathrm{mg} \mathrm{N} \mathrm{m}^{-2}$ bi-monthly ${ }^{-1}$

$111 \mathrm{mg} \mathrm{N} \mathrm{m}^{-2}$ bi-monthly ${ }^{-1}$ for Anholt. The return period on nitrogen wet deposition has been calculated using the method described in Eqs. (5-8). The result for summer conditions, here defined as May to August, is given in Fig. 2 and Table 1. The one-year maximum reoccurrence value is $62 \mathrm{mg} \mathrm{N} \mathrm{m}^{-2}$ bi-monthly ${ }^{-1}$, whereas the 10 -year maximum value is $92 \mathrm{mg} \mathrm{N} \mathrm{m}^{-2}$ bi-monthly ${ }^{-1}$. If the tail of the distribution of bi-monthly wet deposition is exponential, then the extreme wet depositions have an accumulated probability that is double exponential. This is successfully checked and shown in Fig. 3a. The extreme events for the full year are also listed in Table 1 and it is seen that only slightly higher extreme wet nitrogen deposition events are predicted than for the summer periods.

Extreme events at a daily time scale are of much greater interest than bi-monthly values because phytoplankton communities typically doubles within one day. Furthermore, the nitrogen contributed to the surface layer is well-mixed in less than 30 minutes, hence is readily available for $C_{a}$ growth.

Daily observations of wet deposition are not available from Anholt. Therefore two approaches are taken to estimate the order of magnitude. One is based on analysis of daily nitrogen wet deposition observations at a rural site $140 \mathrm{~km}$ southwest of Anholt (Tange in Jutland at location UTM 32 N6246 E537). The other approach is based on daily nitrogen wet deposition model results for the Kattegat Sea.

Tange daily observations

A data series from Tange has been analyzed in regard to extreme reoccurrence values of nitrogen wet-deposition calculated as the sum of nitrogen $\left(\mathrm{NO}_{3}\right.$ and $\left.\mathrm{NH}_{4}\right)$ for Tange. The daily observations at Tange show an average nitrogen wet deposition of $709 \mathrm{mg} \mathrm{N} \mathrm{m}^{2}$ year $^{-1}$ in the period 1989 to 1997 . Bi-monthly observations at Tange show $851 \mathrm{mg} \mathrm{N} \mathrm{m}^{2}$ year $^{-1}$ in the period 1989 to 1998 . The average value at Anholt sampled bi-monthly is $756 \mathrm{mg} \mathrm{N} \mathrm{m}^{2}$ year $^{-1}$ in the period 1989 to 2001. Hence the marine site at Anholt receives around $17 \%$ less nitrogen wet-deposition than the rural site at Tange. The distance between the sites is $140 \mathrm{~km}$.

The daily nitrogen wet deposition samples from Tange are used for an order of magnitude study on reoccurrence values. It is anticipated that extreme high deposition events are relatively better logged by the "closed" system than smaller deposition events. The open system on the other hand, may be polluted by biological material e.g. from birds. The data set is carefully screened prior to the extreme events analysis (and also tested for the Gumbel distribution).

Daily nitrogen wet deposition reoccurrence values for one-, 10- and 100-years from Tange are listed in Table 1 and the values between one- and 10-years are shown in Fig. 2 . The data set is reasonably described by a double-exponential function (Fig. 3b). Table 1 shows that at Tange the difference in extremes for summers only (May to August) and the full year is insignificant. In other words, the extreme nitrogen wet deposition typically occurs during summer at Tange.

The one-year reoccurrence for nitrogen wet deposition at Tange is $32 \mathrm{mg} \mathrm{N} \mathrm{m}^{-2}$ day $^{-1}$. That is a half of the bimonthly value at Anholt $\left(62 \mathrm{mg} \mathrm{N} \mathrm{m}^{2} \mathrm{day}^{-1}\right)$. The 10 -year reoccurrence value at Tange is $76 \mathrm{mg} \mathrm{N} \mathrm{m}^{2}$ day $^{-1}$ (83\% of the Anholt value at $92 \mathrm{mg} \mathrm{N} \mathrm{m}^{2} \mathrm{day}^{-1}$ ). The two curves on wet deposition in Fig. 2 have the same shape. In conclusion, the study on daily wet deposition events at Tange indicates that daily and bi-monthly extreme values are of the same order of magnitude.

\section{ACDEP daily model results}

Daily wet deposition model results from a one-year period in year 2001 are analysed. The model results are from the ACDEP model using the Eta-model meteorology as boundary condition. Three grid cells $(30 \mathrm{~km}$ by $30 \mathrm{~km})$ 
Table 2. Daily nitrogen wet and dry deposition values for three $30 \mathrm{~km}$ by $30 \mathrm{~km}$ grid cells in the Kattegat basin from the ACDEP model listed as maximum values and averages (in brackets) in $\mathrm{mg} \mathrm{N} \mathrm{m}^{-2}$ day $^{-1}$ for the full year of 2001

\begin{tabular}{cccc}
\hline & North basin & Central basin & South basin \\
\hline Dry deposition & $5.7(2.3)$ & $4.5(1.1)$ & $3.7(1.0)$ \\
Wet deposition & $162.4(3.9)$ & $129.3(3.4)$ & $64.2(3.4)$ \\
Total deposition & $165.7(6.2)$ & $130.9(4.3)$ & $66.3(4.4)$ \\
\hline
\end{tabular}

are selected such that these include only water surfaces and are representative for the three sub-basins shown in Fig. 1. The yearly maximum and average values are extracted and listed in Table 2. Anholt is located between the Central and Southern basins, i.e. the mean extreme value is $97 \mathrm{mg} \mathrm{N} \mathrm{m}^{-2}$ day $^{-1}$ for year 2001 (averaging the extreme for the two basins). The value is somewhat higher than the 10-year bi-monthly reoccurrence value (Table 1) for the full year. Furthermore it may be noted that the extreme event in year 2001 in the grid cell representative for the Northern sub-basin is even larger ( $162 \mathrm{mg} \mathrm{N} \mathrm{m}^{-2}$ day $\left.^{-1}\right)$.

Two recent studies on total atmospheric nitrogen deposition based on the ACDEP model with Eta boundary conditions for the North Sea and the Kattegat Strait show significant spatial and temporal variations. Hertel et al. (2002) present results of a significant spatial gradient (around an order of magnitude) in atmospheric nitrogen deposition over the North Sea in year 1999 and Ambelas Skjøth et al. (2002) show a temporal variation of $100 \%$ in atmospheric nitrogen wet deposition to the Kattegat Strait within the years 19961999. The spatial variation mainly is explained by the distance to the sources of nitrogen emission whereas the temporal variation mainly is explained by relatively dry and wet years.

It is beyond the scope of the present study to go into further detail with the ACDEP model results. These are used only as guidance for drawing a tentative conclusion that the extreme wet deposition events measured at Anholt may be contributed to daily events within the two-week period of observations. In other words, the curve on wet deposition extreme events (Fig. 2) and the values in Table 1 could be interpreted as $\mathrm{mg} \mathrm{N} \mathrm{m}^{-2}$ day $^{-1}$ instead of as $\mathrm{mg} \mathrm{N} \mathrm{m}^{-2}$ bimonthly ${ }^{-1}$ without much exaggeration.

On average the total wet deposition is around $2.6 \mathrm{mg} \mathrm{N} \mathrm{m}^{-2} \mathrm{day}^{-1}$ in the summer period during the last decade according observations at Anholt (Table 3). The average deposition is rather constant whereas the extreme values are highly variable and an order of 20 to 40 times larger than the average values. The ACDEP model results (Table 2) indicate some variation in the average and maximum wet deposition values over the Kattegat Strait (also found by Asman et al., 1995) but the spatial distribution on extreme events cannot be inferred from the present dataset covering only one year.
The analysis results lead to three conclusions on the extreme nitrogen wet deposition events to the Kattegat Strait

- the yearly reoccurrence extreme wet deposition event is around $60 \mathrm{mg} \mathrm{N} \mathrm{m}^{-2}$ day $^{-1}$

- the extreme bi-monthly wet deposition at Anholt seems to relate to rain events at a time scale equal to or shorter than one day

- the extreme wet deposition may not be homogeneously distributed over the Kattegat Strait

\subsubsection{Dry deposition}

The values of total nitrogen dry deposition at a daily time scale during 12 years representative for the sea near Anholt are analysed. The extreme events at 1, 10 and 100-year reoccurrence intervals are calculated using Eqs. (4-7) and are shown in Table 1 and Fig. 2 (and successfully checked for a Gumbel probability distribution, Fig. 3c). It is clear that the dry deposition extreme values are much lower than for wet deposition. The yearly average values are listed in Table 3 and it shows that the yearly average dry deposition is lower than the yearly average wet deposition values by a factor of ten. The spatial variation in dry deposition is represented from three ACDEP model grid cells $(30 \mathrm{~km}$ by $30 \mathrm{~km})$ and the results are listed in Table 2. Some variation is seen between the grid cells and the variation between average and maximum dry deposition for year 2001 is found to be a factor of two to three. This is much smaller than for wet deposition where the factor between average values and extreme events ranges from 20 to 40 .

\subsection{Nitrogen flux from deep-water entrainment}

A basin-scale hydrodynamic model has been used to estimate the flux of nutrients to the mixed layer by wind forced entrainment. The hydrodynamic model resolves the Kattegat horizontally with three sub-basins (see Fig. 1) and in the vertical with 50 layers. The model also covers the remaining of the Baltic Entrance Area and the Baltic Sea. The mixed layer dynamics is parameterised with a bulk approach. The details of the model are given in Gustafsson (2000).

The main focus of this calculation is to estimate the magnitude and frequency of mixing events that can feed the mixed layer with nutrients from below. The methodology is to use observed salinity-nutrient relations with a monthly resolution together with the modelled entrainment rate to estimate the daily nutrient flux. However, decreasing wind speeds and/or increasing buoyancy flux due to heating or freshwater supply can lower the turbulent kinetic energy in the mixed layer. That causes the mixed layer thickness to decrease. During variable weather conditions, the mixed layer thickness can increase and decrease frequently without substantial upward transport of deep-water. 
Table 3. Mean summer month (May to August) values of chlorophyll a concentration $\left(C_{a}\right)$ and number of samples $(\mathrm{N})$ in the Kattegat Strait 1989-1999 from NERI and SMHI monitoring network; atmospheric nitrogen wet and dry deposition and their sum from Anholt from NERI; deep-water flux entrainment of nitrogen in three basins (see Fig. 1) in the Kattegat Strait based on hydro dynamical model results from Univ. of Gothenburg. The total flux from the atmosphere and the deep-water entrainment is given in the last column for the Central Kattegat Strait

\begin{tabular}{ccc|ccc|ccc|c}
\hline \multicolumn{3}{c}{ Chlorophyll a $^{1}$} & \multicolumn{3}{c}{ Atmospheric deposition } & \multicolumn{2}{c}{ Deep-water flux } \\
\hline Year & $\begin{array}{c}C_{a} \\
\left(\mathrm{mg} \mathrm{m}^{-3}\right)\end{array}$ & $\mathrm{N}$ & $\begin{array}{c}\text { wet } \\
\mathrm{mg} \mathrm{N} \mathrm{m}^{-2} \mathrm{day}^{-1}\end{array}$ & $\begin{array}{c}\text { dry } \\
\mathrm{mg} \mathrm{N} \mathrm{m}^{-2} \mathrm{day}^{-1}\end{array}$ & $\begin{array}{c}\text { sum } \\
\mathrm{mg} \mathrm{N} \mathrm{m}^{-2} \mathrm{day}^{-1}\end{array}$ & $\begin{array}{c}\text { north } \\
\mathrm{mg} \mathrm{N} \mathrm{m}^{-2} \mathrm{day}^{-1}\end{array}$ & $\begin{array}{c}\text { central } \\
\mathrm{mg} \mathrm{N} \mathrm{m}^{-2} \text { day }^{-1}\end{array}$ & $\begin{array}{c}\text { south } \\
\mathrm{mg} \mathrm{N} \mathrm{m}^{-2} \text { day }^{-1}\end{array}$ & $\begin{array}{c}\text { central } \\
\mathrm{mg} \mathrm{N} \mathrm{m}^{-2} \mathrm{day}^{-1}\end{array}$ \\
\hline 1989 & 1.94 & 78 & 2.7 & n.a. & 2.7 & 22.5 & 4.5 & 4.4 & 7.1 \\
1990 & 2.40 & 100 & 2.9 & 0.2 & 3.1 & 12.0 & 0.8 & 1.4 & 4.5 \\
1991 & 2.03 & 106 & 2.4 & 0.2 & 2.6 & 17.2 & 4.4 & 6.0 & 8.6 \\
1992 & 2.11 & 98 & 2.7 & 0.3 & 3.0 & 5.8 & 0.8 & 0.6 & 3.6 \\
1993 & 1.80 & 168 & 2.4 & 0.2 & 2.6 & 5.8 & 1.7 & 1.4 & 4 \\
1994 & 2.11 & 176 & 3.0 & 0.2 & 3.2 & 12.2 & 1.5 & 1.3 & 4.5 \\
1995 & 1.95 & 202 & 2.5 & 0.2 & 2.7 & 3.0 & 0.8 & 0.6 & 3.3 \\
1996 & 1.56 & 139 & 2.4 & 0.2 & 2.6 & 6.3 & 1.8 & 1.4 & 4 \\
1997 & 1.41 & 186 & 2.5 & 0.2 & 2.7 & 0.2 & 0.1 & 0.1 & 2.8 \\
1998 & 2.11 & 153 & 2.2 & 0.1 & 2.3 & 6.0 & 1.3 & 1.6 & 3.9 \\
1999 & 1.91 & 187 & 2.6 & 0.1 & 2.7 & 0.5 & 0.2 & 0.2 & 2.9 \\
average & 1.94 & 2.6 & 0.2 & 2.7 & 8.3 & 1.6 & 1.7 & 4.5 \\
\hline
\end{tabular}

When the wind speed increases and/or the buoyancy supply ceases, the erosion will start by entraining water that recently was within the mixed layer. Especially during summer, this water will be nearly depleted of nutrients and not give a substantial increase of nutrients to the mixed layer. Thus it is necessary to separate between entrainment of old mixed layer water and nutrient rich deep-water. In principle, this could be done by the use of salinity-nutrient relations. However as the salinity difference may be small and the model error comparatively large, it is not a practical method.

Instead an artificial "tracer" is introduced into the model. The "tracer" has a concentration equal to 1 in the Skagerrak water (which feeds the deep-water of Kattegat) and a concentration equal to 0 in the surface mixed layer. This "tracer" is used as a weight factor for estimating the entrainment of nutrient rich deep-water.

The entrainment flux is calculated at each time-step by firstly estimating a nutrient concentration profile in the model from the salinity-nutrient relation for that month, secondly summing up the entrainment of nutrients using

$F=\int_{t}^{t+\Delta t} w_{E} C_{N} C_{W} d t$

with $w_{E}$ the entrainment rate, $C_{N}$ the nutrient concentration and $C_{W}$ the concentration of the "tracer" that approximates the relative amount of deep-water. The nutrient fluxes calculated in this way will probably not give the total upwelling of nutrients in Kattegat, but the resulting time-series represent an order of magnitude estimate of the entrainment fluxes and their frequency.
The calculations are done for the period 1976-1999 with the observed salinity-nutrient relations from Rasmussen and Gustafsson (2003). The fluxes appear to be somewhat higher in the Southern than in Central Kattegat. This is mainly explained from the fact that there are larger shallow areas in Central Kattegat above the halocline depth whereas the Southern basin is deeper. The maximum fluxes of dissolved inorganic nitrogen reach values as high as $600 \mathrm{mg} \mathrm{N} \mathrm{m}^{2}$ day ${ }^{1}$. The Northern Kattegat has much higher fluxes due to the influx of nutrient-rich water from the Skagerrak. A 10-year average on nitrogen flux values is listed in Table 3 for the summer period. The average values vary greatly between the three sub-basins from $8.3 \mathrm{mg} \mathrm{N} \mathrm{m}^{2}$ day ${ }^{1}$ in the Northern basin to $1.6 \mathrm{mg} \mathrm{N} \mathrm{m}^{2}$ day $^{1}$ in the Southern basin. Furthermore there are large interannual variations e.g. ranging from 0.1 to $4.5 \mathrm{mg} \mathrm{N} \mathrm{m}^{2}$ day ${ }^{1}$ for the Central basin during the decade from 1989-1999.

The extreme events are calculated from 25 years of daily model results using Eqs. (4-7). The results are shown in Table 1 and Fig. 2. The results show very large variations in space and time. The extreme one-year reoccurrence values in summers and for the full year are very different. In the summers, for the Central basin, the extreme value is $27 \mathrm{mg} \mathrm{N} \mathrm{m}^{2}$ day ${ }^{1}$ whereas the value is $114 \mathrm{mg} \mathrm{N} \mathrm{m}^{2}$ day $^{1}$ for the full year. The dynamics are also very different between the basins, especially for the Northern basin where the extreme one-year reoccurrence value is $173 \mathrm{mg} \mathrm{N} \mathrm{m}^{2}$ day ${ }^{1}$. The data set is successfully checked for the Gumbel probability distribution (Fig. 3d). 

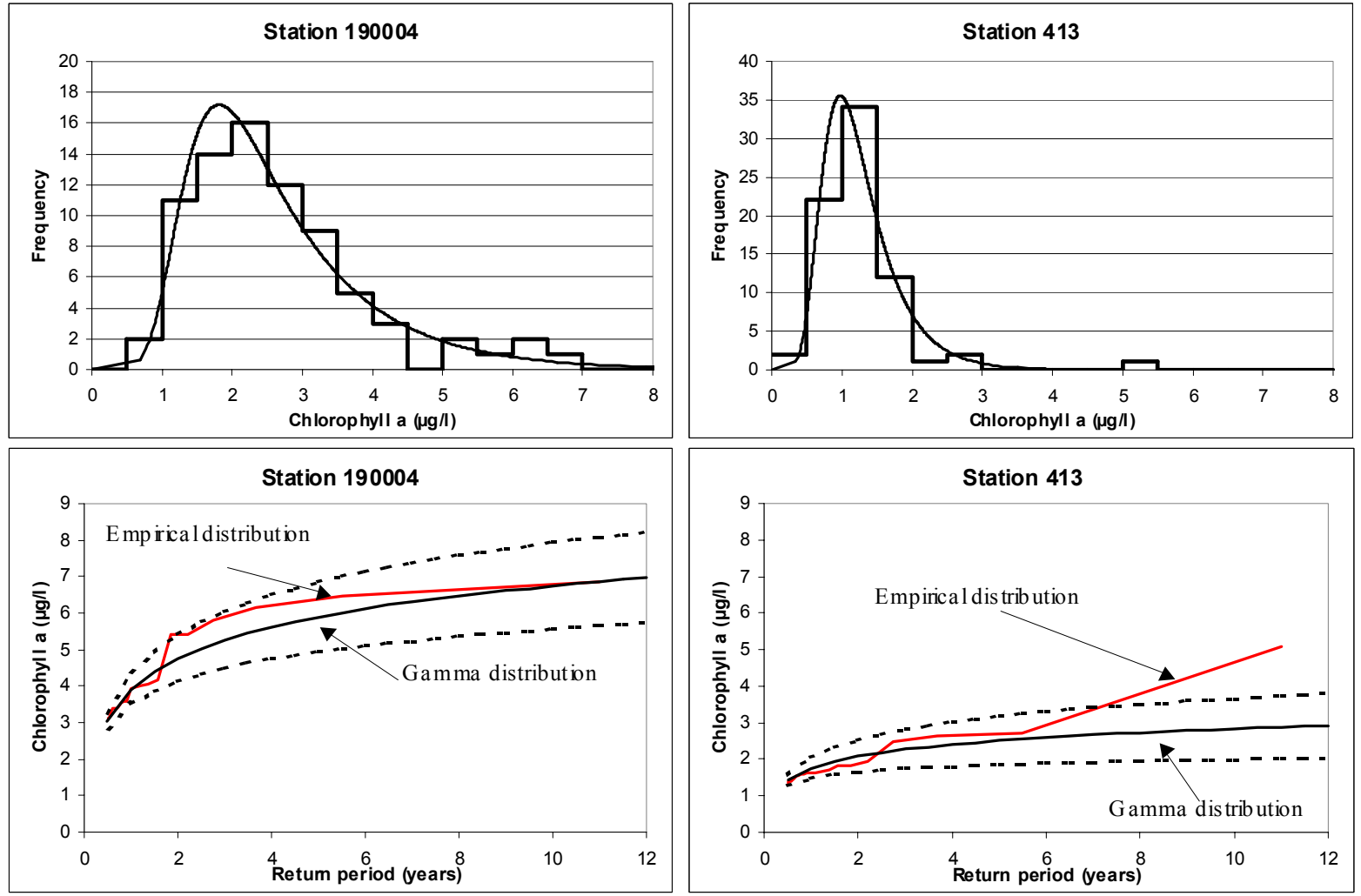

Fig. 4. The upper graphs show the empirical and estimated Gamma distribution for summer surface chlorophyll a at a coastal station (Station 190004) and an open sea station (Station 413). The lower graphs show chlorophyll a concentrations as a function of return period calculated from the empirical and Gamma distribution.

\subsection{Chlorophyll a}

The combined dataset on in-situ $C_{a}$ observations in the Kattegat Strait from the Danish and Swedish monitoring authorities are analysed. The sampling sites include a total of 50 stations (see Fig. 5) with a sampling rate of 3 weeks or less (1989 to 1999). Only samples from the top 10 meters of the water column are considered for assessing the effect of atmospheric deposition. The average level of $C_{a}$ over the entire Kattegat basin was $1.94 \mathrm{mg} \mathrm{m}^{-3}$ based on the 1593 observations (Table 3). A spatial analysis revealed that the average $C_{a}$ value is less than $1.4 \mathrm{mg} \mathrm{m}^{-3}$ in the Southern part increasing to above $2 \mathrm{mg} \mathrm{m}^{-3}$ near the coasts and in the Northern sub-basin (Hasager et al., 2003).

From a statistical analysis it is found that the $C_{a}$ frequency distributions are Gamma distributed both in the relatively nutrient poor waters in the Southern basin and in the relatively nutrient rich waters close to the Jutlandic coast. The Gamma distributions fitted to data from two stations are shown in Fig. 4 with calculated $C_{a}$ concentrations versus return periods between 1 and 12 years. Figure 4 shows that blooms of a given magnitude will occur much more frequent at the coastal station (station 190004) compared to the open sea station (station 413).
The spatial pattern of the expected maximum chlorophyll a level for the Kattegat Strait is calculated for a 10-year return period for all stations and the map is shown in Fig. 5. This reveals that the western part of the Kattegat Strait is likely to experience $C_{a}$ levels up to $7 \mathrm{mg} \mathrm{m}^{-3}$ whereas the southern part most likely will only experience up to $4 \mathrm{mg} \mathrm{m}^{-3}$ within a decade. Some areas in the Kattegat Strait are identified as zones with a high probability of generating blooms.

These areas are

1. the southern part where the Great Belt and the Sound flow into the Kattegat Strait,

2. the frontal zone where Skagerrak mixes with the Kattegat Strait,

3. the eastern part of the Kattegat Strait.

For the first two, a strong periodic turbulent mixing characterise the water masses. For the third, it is a combination of the fact that the shallow eastern part of the Kattegat Strait easily will have an in-flux of nutrient rich deep-water but also that the major freshwater sources may dispatch nutrients to the sea along the east-Jutlandic coastline.

Out of a total of $1786 C_{a}$ observations, 233 were estimated to be bloom events based on the graphs per station like those 


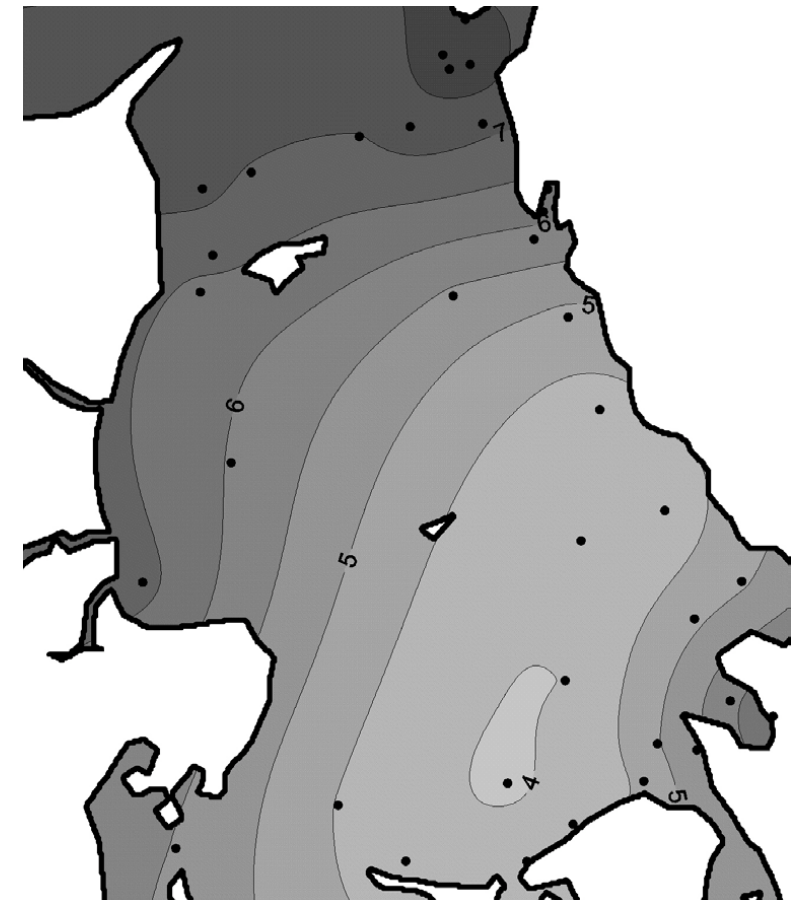

Fig. 5. The spatial distribution of expected chlorophyll a level in $\mathrm{mg} \mathrm{m}^{-3}$ with a 10 -year return period based on weekly independent samples in the Kattegat Strait. The dots indicate the locations of the sampling sites used by the Danish and Swedish monitoring authorities.

in Fig. 4 for station 190004 where blooms appear when $C_{a}>$ $4 \mathrm{mg} \mathrm{m}^{-3}$ and for station 413 where blooms appear for $C_{a}>$ $2 \mathrm{mg} \mathrm{m}^{-3}$. From the statistical analysis on $C_{a}$, it occurs that a few algal blooms may have occured in the early 1990'ties, i.e. in the period after the CZCS but prior to the OCTS, POLDER and SeaWiFS sensors. NOAA AVHRR data are rather cloudy on all the days where algal blooms are likely to have occurred except at one satellite scene that shows a SST gradient from $14^{\circ} \mathrm{C}$ in the northern part of the Kattegat Strait to $17^{\circ} \mathrm{C}$ near Anholt. No clear SST anomalies are detected. Please refer to Hasager et al. (2003) for further detail on these algal bloom events and their species composition. It can be mentioned that the algal bloom in 1988 (Johannessen et al., 1989) started to appear where the highest $C_{a}$ may be expected according to the results in Fig. 5. In the following days it then moved towards the Norwegian coastline.

\subsection{SeaWiFS case study}

Five $C_{a}$-maps from SeaWiFS satellite scenes retrieved by the OC4 $v 4$ algorithm (Eqs. 1-2) are compared to in-situ $C_{a}$ observations from a buoy (four cases) and to ScanFish observations (one case).

Comparison of the $C_{a}$ values from the buoy and SeaWiFS is shown in Fig. 7 and listed in Table 4. It is clear that the SeaWiFS observations are much higher than the buoy ob-
Table 4. Chlorophyll a values from a buoy and from SeaWiFS from the center pixel and the mean, minimum, maximum and standard deviation from a 3 by 3 window centered at the buoy. Unit is $\mathrm{mg} \mathrm{m}^{-3}$

\begin{tabular}{cccccccc}
\hline & Buoy & Center & Mean & Min. & Max. & Std. dev. & Pixels \\
\hline 20010513 & 0.3 & 1.9 & 2.8 & 1.9 & 4.0 & 0.7 & 9 \\
20000519 & 1.8 & 4.1 & 4.5 & 3.3 & 6.1 & 0.8 & 9 \\
20010527 & n.a. & 2.8 & 2.8 & 2.3 & 3.5 & 0.4 & 9 \\
20010604 & 0.6 & 1.7 & 1.7 & 1.5 & 1.9 & 0.2 & 9 \\
20010805 & n.a. & 1.5 & 1.5 & 1.4 & 1.5 & 0.1 & 9 \\
20010807 & n.a. & 2.4 & 2.1 & 1.4 & 2.4 & 0.4 & $5^{*}$ \\
\hline
\end{tabular}

* the other pixels are cloud covered

servations. The observations are collected very closely in time (less than \pm 30 minute) and in space (less than $1 \mathrm{~km}$ distance). The buoy observations on $C_{a}$ vary greatly at a diurnal time scale from $8 \mathrm{mg} \mathrm{m}^{-3}$ in the night to less than $2 \mathrm{mg} \mathrm{m}^{-3}$ during the following day measured at a depth of $-2 \mathrm{~m}$ (Fig. 7). The diurnal variation in chlorophyll a fluorescence is to be expected. It could be attributed to real changes in phytoplankton biomass because of e.g. vertical migration. However, it is more likely that a physiological phenomenon is observed. The sun acts as a large excitation light, which stimulates the chlorophyll fluorescence in the phytoplankton. The in-situ instrument, which has its own excitation light source, thus will measure a lower emission from the phytoplankton during daytime. It is likely that the data from around midnight reflect the true chlorophyll concentrations (pers. comm. Bengt Karlson).

All SeaWiFS scenes are recorded around an hour after local noon. The spatial variation in $C_{a}$ from SeaWiFS is moderate in four cases (see standard deviation in Table 4 in the local area around the position of the buoy. This local variation however does not indicate any values in the range of the buoy. The buoy is moored at more than $-70 \mathrm{~m}$ water depth, hence limitations of SeaWiFS related to shallow waters $(<10 \mathrm{~m}$ water depth) does not explain the relatively high $C_{a}$ values found in SeaWiFS.

In early August 2001, a series of ScanFish observations were collected and the position of all ship tracks are shown in Fig. 7. It may be noted that the ScanFish sampling only took place at areas characterized by relatively deep water ( $>-40 \mathrm{~m}$ depth). Only one cloud free SeaWiFS scene is recorded close in time to the ScanFish sampling. The map of $C_{a}$ from the SeaWiFS scene is shown in Fig. 8. The scene is recorded on 7 August, 2001 at 14:55 p.m. During this day four ScanFish tracks were collected (number 2, 3, 4 and 5 in Fig. 7) and the values of $C_{a}$ from the upper $5 \mathrm{~m}$ over the mixed surface layer are averaged along the horizontal transects and compared to the SeaWiFS observations in Fig. 9.

The first three transects (Fig. 8) show lower $C_{a}$ values in 


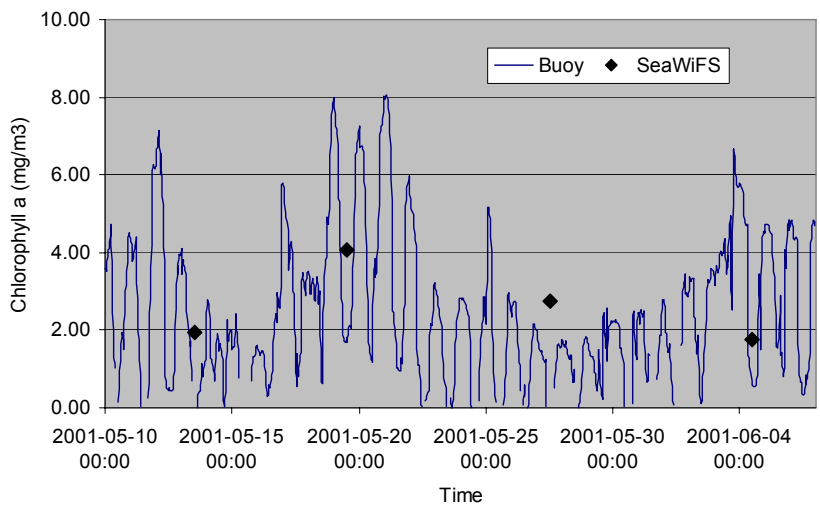

Fig. 6. Chlorophyll a concentration observed at a buoy in the Kattegat Strait per hour and observed by the SeaWiFS satellite (pixel collocated with buoy).

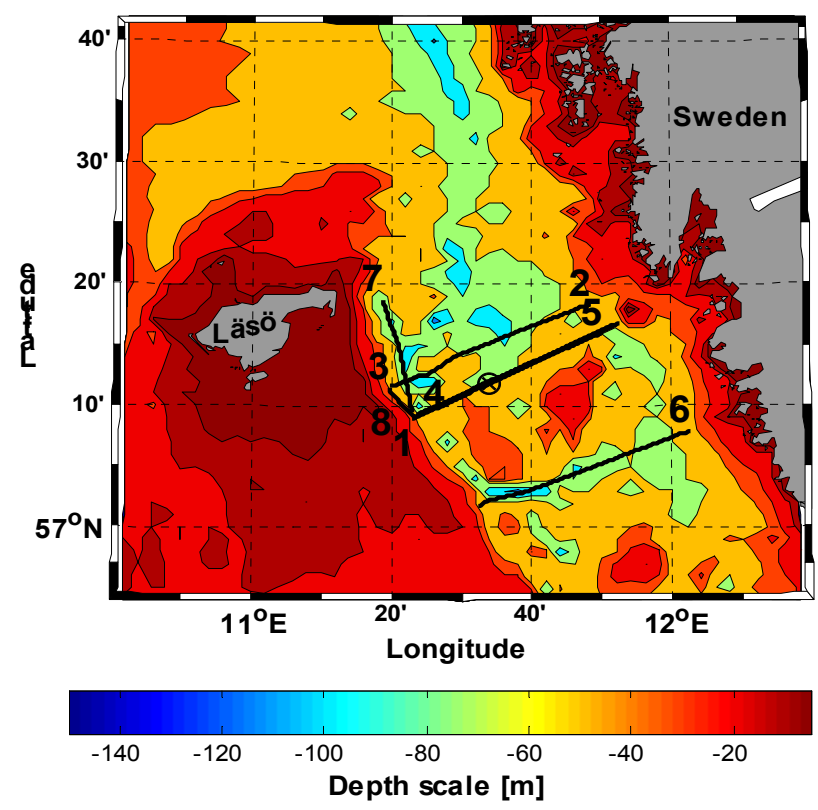

Fig. 7. Ship tracks of ScanFish on the 6 to 10 August 2001 in the Kattegat Strait. The buoy is moored at the position $\oplus$. The transect starts where the number is indicated, e.g. track 2 (East to West), track 3 (North to south), track 4, (West to East) and track 5 (East to West). Track 2, 3 and 4 are recorded 7-9 hours prior to the SeaWiFS observation. Track 5 is recorded only 15 minutes to 2.5 hours after the SeaWiFS observation.

the SeaWiFS scene than from ScanFish. The three ScanFish transects were collected from 6:04 to 10:13 a.m. There is a time difference in sampling of 7-9 hours between the SeaWiFS and ScanFish observations. This is thought to explain that the values are very different.

The fourth transect (Fig. 9d) was collected from 15:13 to 17:25 p.m. local time. This means that the first few kilometres of track 5 are nearly collocated in time to the Sea-
WiFS scene (14:55 p.m.). ScanFish started to sample track 5 only 18 minutes after the SeaWiFS scene was recorded. The ship reached the 8-km distance around 37 minutes later. During the first 8-km the $C_{a}$ values from SeaWiFS and ScanFish compare reasonably. However after 8-km SeaWiFS and ScanFish $C_{a}$ values deviates considerably due to the time difference in observations. The buoy is geolocated at ScanFish track 4 and 5 but unfortunately $C_{a}$ was not successfully observed at the buoy.

In summary, $C_{a}$ was observed from an experimental buoy equipped with a flourometer and from ScanFish flourometer observations in the Kattegat Strait during the summer of year 2001. Comparisons to the SeaWiFS satellite $C_{a}$ maps reveals rather large deviations between the three types of observations. SeaWiFS and ScanFish seem to correspond well when almost truly collocated in space and time. Both sensors provide estimates of the spatial distribution of $C_{a}$ and this is very important as the spatial variation is found to be large in the Kattegat Strait. The SeaWiFS and buoy observations are well collocated in time and space. The large differences in $C_{a}$ values between the two are most likely due to the sun acting as a light source during daytime, thus the chlorophyll level is measured too low at the in-situ buoy.

\section{Discussion on the extreme events}

The average annual atmospheric deposition is $2.7 \mathrm{mg} \mathrm{N} \mathrm{m}^{-2} \mathrm{day}^{-1}$ in the last decade at the island of Anholt in the middle of the Kattegat Strait. The average annual deep-water nitrogen flux is $1.6 \mathrm{mg} \mathrm{N} \mathrm{m}^{-2}$ day $^{-1}$ in the Central and Southern Kattegat basin (Table 3) in the same period. Hence the yearly cumulated contribution from the atmosphere is larger than the cumulated deep-water nitrogen flux in those two sub-basins in the summer periods. Only in the Northern basin is the cumulated deep-water flux of much greater importance than the atmospheric deposition. The nitrogen fuels the phytoplankton communities but only in cases of extreme nitrogen flux events will an algal bloom be able to develop. The average values for the summer period (Table 3) do not show any correlation between high $C_{a}$ and input of nitrogen from the atmosphere and deep-water entrainment. The usual condition is that the surface layer is depleted of nutrients in the summer period, i.e. the average input from the atmosphere and the deep-water entrainment values totalling $4.5 \mathrm{mg} \mathrm{N} \mathrm{m}^{-2} \mathrm{day}^{-1}$ (see Table 3) is efficiently digested. Both the calculated deep-water nitrogen and the atmospheric nitrogen deposition are readily available for phytoplankton growth.

The atmospheric dry deposition events seem too small to support an algal bloom alone, as the one-year reoccurrence of extreme event is around $0.7 \mathrm{mg} \mathrm{N} \mathrm{m}^{2}$ day $^{-1}$ in the summer period. The atmospheric wet deposition events on the other hand seem large enough to increase the growth by some percent (e.g. of the order 20-50\%). 


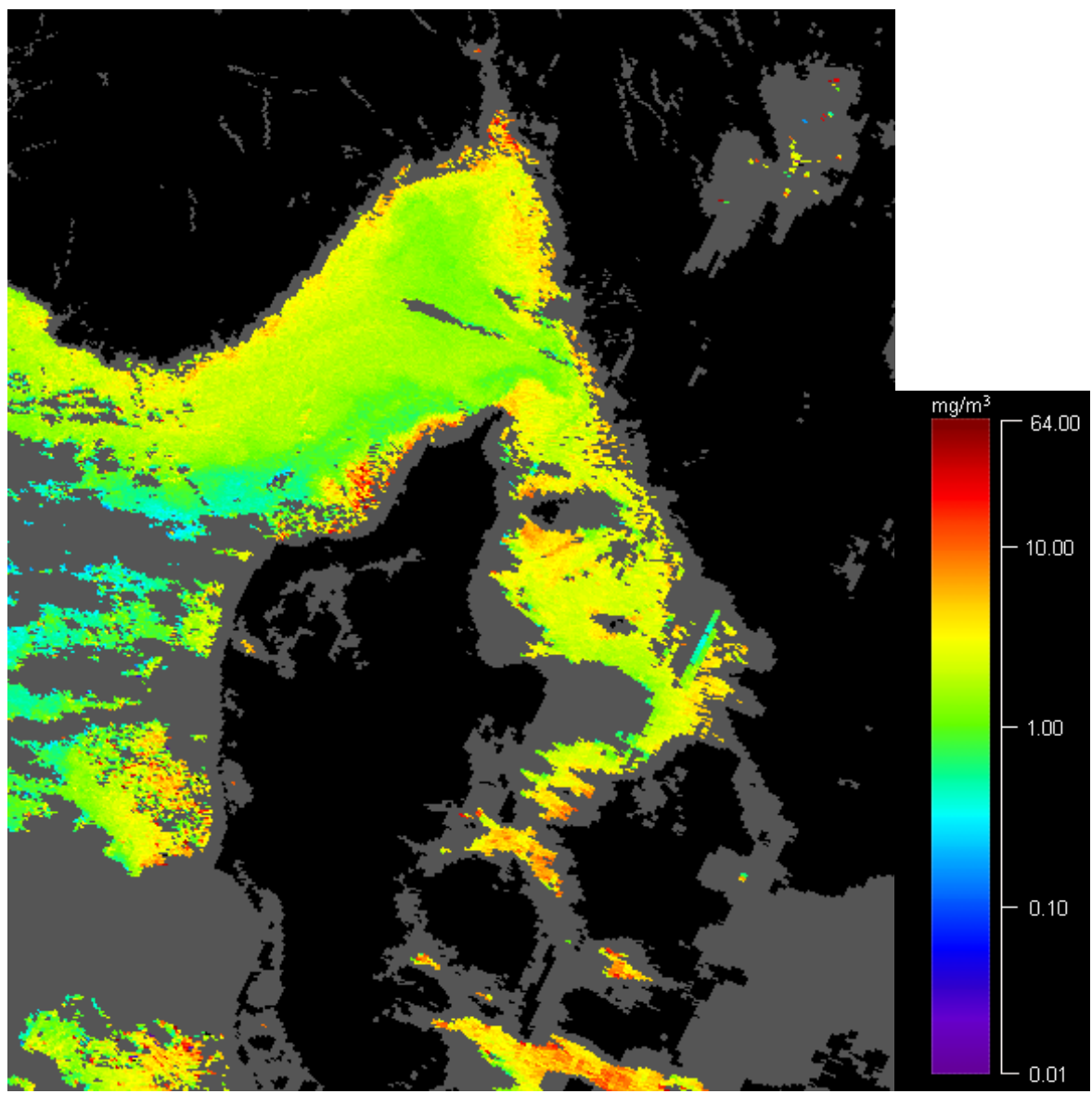

Fig. 8. Chlorophyll a map derived from SeaWiFS by the OC4v4 algorithm for the Danish waters.

The Anholt bi-monthly measurements on nitrogen wet deposition compared to daily observations at Tange and to daily model results, indicate a one-year reoccurrence extreme events of $60 \mathrm{mg} \mathrm{N} \mathrm{m}^{2}$ day $^{-1}$. Wet deposition of particles and passive tracers is known to occur in the very beginning of a rain event and that the air is "clean" already after few minutes, hence an extreme wet nitrogen deposition most likely could occur at a time scale of less than 15 minutes. The mixing time scale of the water surface layer is of the order of 30-minutes, hence the nutrients are readily available for the phytoplankton community. The doubling rate of phytoplankton is about one day.

The deep-water nitrogen flux extreme event statistics is based on 25 years of model results. In the summer months the deep-water flux has a one-year reoccurrence value of $27 \mathrm{mg} \mathrm{N} \mathrm{m}^{2} \mathrm{day}^{-1}$ in the Central and Southern basin, i.e. a value around half of the extreme wet deposition events. However, at longer times scales e.g. 10 and 100-years, the deepwater nitrogen flux is larger than the extreme atmospheric flux. Another major difference between the extreme nitrogen fluxes from the atmosphere and from the deep-water entrainment is found in the summer period contra the full year. The relative importance of extreme deep-water nitrogen flux events during autumn, winter and spring is significantly larger than the atmospheric deposition events (Table 1). This has to do with the occurrences of stronger winds during autumn and winter driving the deep-water nutrient fluxes, whereas the wet deposition is closer linked to precipitation patterns.

A correlation analysis between $C_{a}$, wind speed, modelled atmospheric nitrogen deposition from the ACDEP at the Kattegat basin scale and modelled deep-water nitrogen flux from the hydrodynamic model has been carried out based on the years 1989 to 1999 (Hasager et al., 2003). The main result is that higher wind speed with a 2-6 day time-lag best explains the bloom situations versus non-bloom situations. This statistical analysis indicates that the physical state (wind speed) of the atmosphere influences $C_{a}$ levels in the Kattegat Strait during the last decade in the summer periods May to August.

It is found that the ACDEP model results on atmospheric nitrogen deposition are not fully reliable at the daily scale due to the fact that the meteorological input may have been too coarse (in time and space) (compare to newer results, Ambelas Skjøth et al. 2002). The newer model results compare 


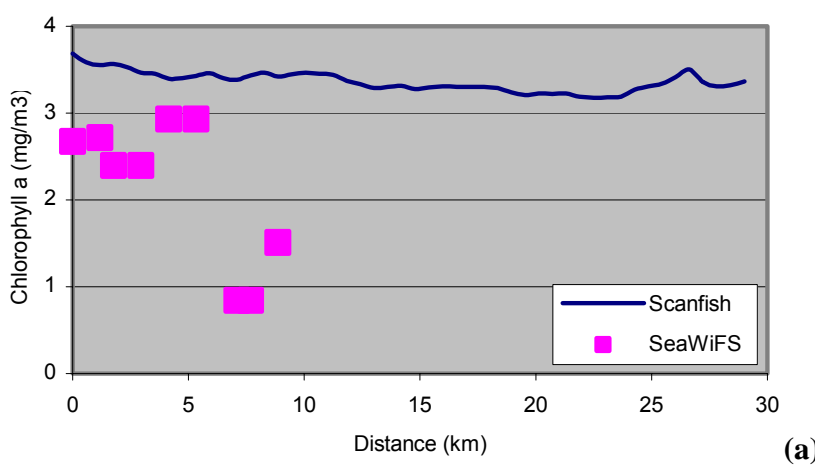

Scanfish and SeaWiFS (track 4)

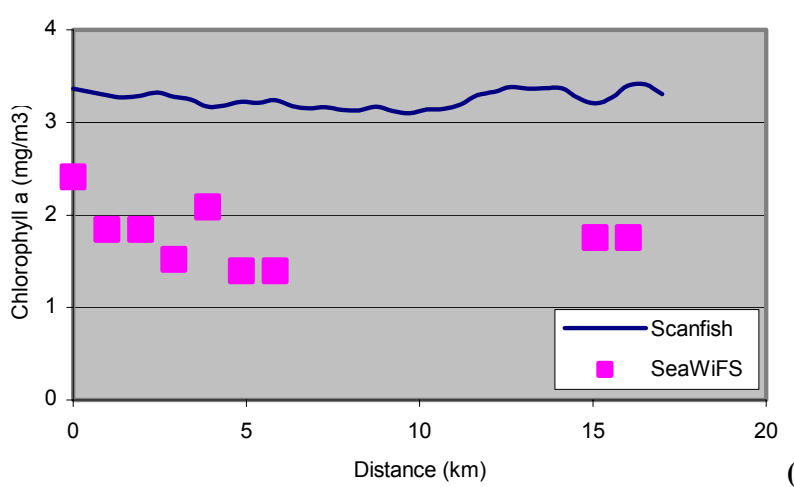

(c)

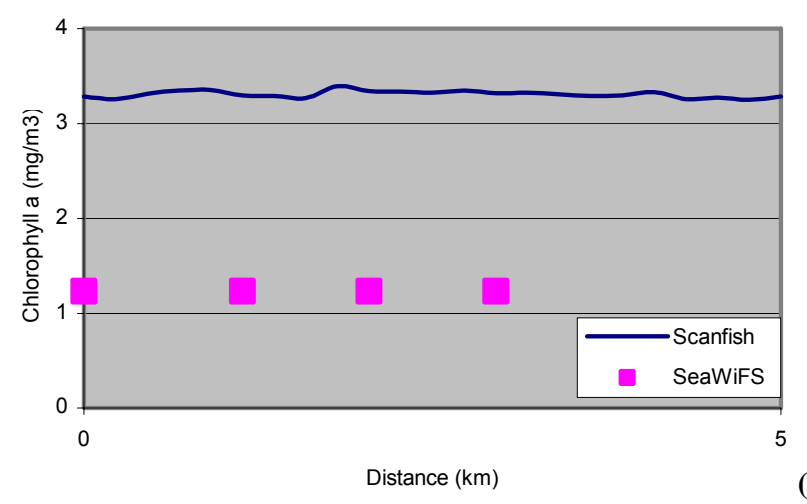

Scanfish and SeaWiFS (track 5)

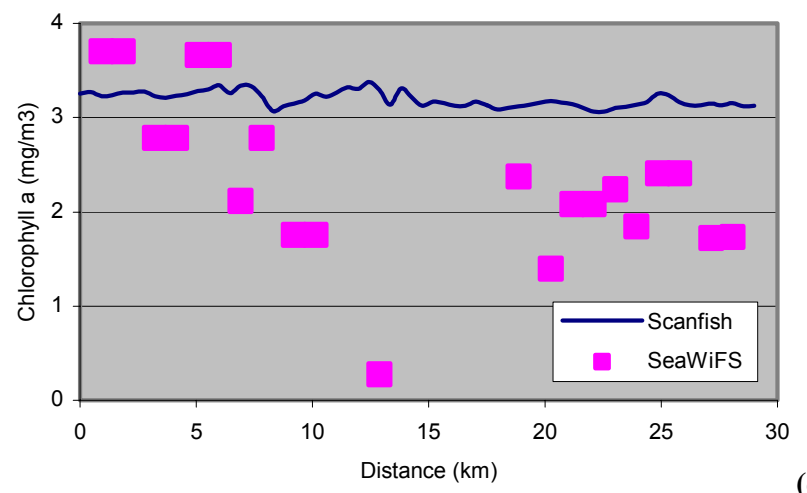

(d)

Fig. 9. ScanFish and SeaWiFS chlorophyll a observations in four horizontal transects in the Kattegat Strait from 7 August 2001. Please refer to Fig. 7 for the geo-position of the ship tracks.

well in the timing and magnitude of single (daily) nitrogen wet deposition events, whereas the older model results do not capture the daily scale well but only the monthly and yearly average values. Hence correlation analysis at daily scale is not really feasible for wet deposition (and the co-existence of strong wind and high wet deposition could not be investigated).

In other words, in the case of very strong winds the whole Kattegat Strait typically is affected by the event. Therefore correlation analysis between high $C_{a}$ and high deep-water nitrogen entrainment flux is likely to be found through correlation analysis if the nitrogen actually fuels the growth (e.g. with a certain time lag). In contrast, a high wet deposition event typically is very local (convective summer precipitation) and the position and timing is not well known. Hence a correlation analysis on wet nitrogen deposition and $C_{a}$ levels at large scale cannot fully reveal the cause-effect relationship even if it is actually existing. It is necessary to map nitrogen wet deposition and $C_{a}$ levels at a higher spatial and temporal resolution to infer this relationship from statistical correlation analysis.
The relative importance of nitrogen wet deposition and deep-water entrainment is reversed between the one-year and the 10-year extreme events as shown in Fig. 2 and Table 1. The reoccurrence value for nitrogen wet deposition quickly levels off as a function of year compared to the steeply increasing nitrogen deep-water flux. The physical explanation of these two behaviours may be related to the actual pool of nitrogen in the atmosphere versus the deep-water nitrogen pool. Only a limited amount of nitrogen may be stored in the atmosphere prior to a heavy rain event whereas the pool of nitrogen at the bottom of the sea is an immense pool from which nutrients steadily are released in response to extreme winds (hurricanes).

So far atmospheric deposition and deep-water entrainment is discussed only at basin or sub-basin scale. However at higher resolution, the daily ACDEP model results in year 2001 shows significant spatial patterns in dry and wet deposition of nitrogen over the Kattegat Strait (Table 2). The spatial resolution of the atmospheric model is $30 \mathrm{~km}$ by $30 \mathrm{~km}$ and the model results for three grid cells located centrally in each of the Kattegat sub-basins defined for the hydro dynamical 
model (Fig. 1) are extracted. The extreme and average values show the same trends as the multi-year records. The extreme value of wet deposition from year 2001 is very high, $162 \mathrm{mg} \mathrm{N} \mathrm{m}^{2}$ day $^{-1}$ in the grid cell for the Northern basin as compared to the extreme statistics for Anholt data (much higher than the 100-year event). It is beyond the scope of the present study to go into detail with the ACDEP model results. However it is interesting to note that in summers, for the Southern and Central basins, a similar $\left(27 \mathrm{mg} \mathrm{N} \mathrm{m}^{2}\right.$ day $\left.^{-1}\right)$ value of the one-year extreme deep-water flux is predicted (Table 1) but that the $C_{a}$ map on 10-year extreme events (Fig. 5) has a minimum in the Southern basin.

The relative importance of nitrogen contributed from atmospheric deposition and deep-water flux to the Kattegat Strait may be highly variable at a scale of e.g. $30 \mathrm{~km}$ by $30 \mathrm{~km}$. Such variations, however, cannot be quantified from the current dataset. The growth of algal blooms typically is local, hence local extreme inputs typically from the atmosphere may be important. The high spatial and temporal variation in $C_{a}$ is documented from the case study (SeaWiFS, buoy and ScanFish observations) within the Kattegat Strait.

\section{Conclusions}

Nitrogen typically is the limiting nutrient for chlorophyll growth in the Kattegat Strait. The retrospective analysis focuses on the vertical nitrogen fluxes to the mixed sea surface layer in which the chlorophyll growth may cause blooms of harmful algae and subsequent turn over and oxygen depletion at the sea bottom. The expected chlorophyll a level with a 10-year return period has been calculated based on in-situ observations and the map shows a gradient from $4 \mathrm{mg} \mathrm{m}^{-3}$ in the southern part of the basin to $8 \mathrm{mg} \mathrm{m}^{-3}$ in the northern part for the summer period (May to August). The most likely input of nitrogen during the summer period is from either the atmosphere or deep-water entrainment as the riverine input is limited.

The reoccurrence values at one, ten and hundred year extreme events of nitrogen fluxes from atmospheric dry and wet deposition and deep-water flux entrainment are calculated. It is found that the one-year reoccurrence value of atmospheric wet deposition is around $60 \mathrm{mg} \mathrm{N} \mathrm{m}^{-2}$ day $^{-1}$ whereas the dry deposition is an order of magnitude smaller. Hence only the first input may trigger a bloom of algae comparing to the Redfield ratio where more than $70 \%$ of the average primary production then would be contributed from the atmospheric input. The one-year reoccurrence value of deep-water nitrogen entrainment is around $30 \mathrm{mg} \mathrm{N} \mathrm{m}^{-2}$ day $^{-1}$ in the Central and Southern part of the Kattegat Strait whereas a much higher value $\left(170 \mathrm{mg} \mathrm{N} \mathrm{m}^{-2} \mathrm{day}^{-1}\right)$ is found in the Northern part. The latter is explained by the proxity to the Skagerrak. The one-year reoccurrence value of nitrogen deep-water entrainment is four times smaller than atmospheric wet deposition in the summer period.
The 10-year reoccurrence value of atmospheric wet deposition is around $90 \mathrm{mg} \mathrm{N} \mathrm{m}^{-2}$ day $^{-1}$ and the deep-water entrainment is around $110 \mathrm{mg} \mathrm{N} \mathrm{m}^{-2}$ day $^{-1}$ in the Central basin, i.e. at this time-scale the extreme events of deep-water flux are larger than the atmospheric wet deposition. This is in contrast to the one-year reoccurrence. The reoccurrence curve for wet deposition gradually reaches a "threshold" that physically is explained by the maximum content of nitrogen the atmosphere may contain prior to a heavy rain event. The reoccurrence curve for deep-water entrainment on the other hand, continues to rise rather steeply. Physically this is a function of extreme wind conditions (hurricanes) where the large pool of nutrients stored at the bottom of the sea readily are released to the surface water.

The map of 10-year chlorophyll a levels in the Kattegat Strait corresponds well to the spatial distribution of nitrogen deep-water flux entrainment as well as to the nitrogen atmospheric wet deposition gradient from a single year. Chlorophyll a levels are highly variable in space and time in the Kattegat Strait as demonstrated from the SeaWiFS, ScanFish and buoy observations from an experimental period.

It is recommended that in-situ chlorophyll observations from monitoring stations in the future are sampled collocated in time with the SeaWiFS and/or ENVISAT MERIS satellite ocean colour Earth Observations. This definitely would be a benefit for future investigations on the chlorophyll conditions in space and time of the Danish waters.

In summary, the occurrence of algal blooms in the Kattegat Strait is likely to happen around a 5 to 10 year time-scale and the deep-water entrainment (driven by strong winds) is the most likely mechanism to fuel an algal bloom. The events of high atmospheric wet deposition could increase the growth of chlorophyll around $20 \%$ or more. The local nature of high nitrogen wet deposition events makes it a challenge to infer the cause-effect relationship at daily time scale between atmospheric deposition and algal blooms.

Acknowledgements. Funding from EC for the project Marine Effects of Atmospheric Deposition project (MEAD) (http://www. uea.ac.uk/env/mead/), contract EVK3-CT-1999-00014 is acknowledged. Furthermore the project S-MEAD granting access to the SeaWiFS satellite scenes from NASA, retrieved from the Dundee station, and GRAS A/S at which Lotte Nyborg and Michael Schultz Rasmussen has contributed by processing of the SeaWiFS scenes is greatly appreciated. Atmospheric observations and model results from Anholt and the ACDEP model (NERI/ATMI), in-situ chlorophyll (NERI/HAMI and SMHI), hydro dynamical model results and ScanFish data (Gothenburg University) and buoy data (SMHI) are acknowledged. Thanks to Søren Ott at Ris $\emptyset$ for discussion on extreme events, to Britta Pedersen at NERI/HAMI for discussion on the HPLC observations and to Bengt Karlsson, SMHI for discussion on the in-situ buoy observations. 


\section{References}

Abild, J.: Application of the wind atlas method to extremes of wind climatology. Technical report Ris $\varnothing-\mathrm{R}-722(\mathrm{EN})$, Ris National Laboratory, 1994.

Ambelas Skjøth, C., Hertel, O., and Ellermann, T.: Use of the ACDEP trajectory model in the Danish nation-wide Background Monitoring Programme, Physics and Chemistry of the Earth, 27, 1469-1477, 2002.

Asman, W. A. H., Hertel, O., Berkowicz, R., Christensen, J., Runge, E. H., Sørensen, L. L., Granby, K., Nielsen, H., Jensen, B., Gryning, S. E., Sempreviva, A. M., Larsen, S. E., Hummelshøj, P., Jensen, N. O., Allerup, P., Jørgensen, J., Madsen, H., Overgaard, S., and Vejen, F.: Atmospheric nitrogen input to the Kattegat Strait. Ophelia, 42, 5-28, 1995.

Dundas I., Johannessen, O. M, Berge, G. and Heimdal, B.: Toxic algal bloom in Scandinavian waters, May-June 1988, Oceanography, april issue, 9-14, 1989.

Ellermann, T., Hertel, O., Skov, H., and Manscher, O. H.: Atmospheric Deposition of Nitrogen. Measuring methods and model calculations. Note: In Danish only! (In Danish: Atmosfærisk deposition af kvælstof. Målemetoder og modelberegninger). National Environmental Research Institute. NERI Technical report no. 174 , pp. 57, 1996.

Ellermann, T., Hertel, O. and Ambelas Skjøth, C.: The Nation-wide Danish Monitoring Programme 1999. Atmospheric Deposition, 1999: In Danish: Vandmiljøplanens overvågningprogram 1999, Atmosfærisk deposition 1999. NERI Technical report no. 332, pp. 120, 2002.

Granéli, E.: Nutrient limitation of phytoplankton biomass in a brackish water bay highly influenced by river discharge. Estuarine, Coastal and Shelf Science, 25, 563-569, 1987.

Gumbel, E. J.: Statistics of Extremes. Columbia University Press, 1958.

Gustafsson, B. G.: Time-dependent modelling of the Baltic Entrance Area. 1. Quantification of circulation and residence times in the Kattegat and the straits of the Baltic Sill. Estuaries, 23(2), 231-252, 2000.

Hansen L., Højerslev, N. K., and Søgaard, H.: Temperature monitoring of the Danish marine environment and the Baltic Sea. Kbenhavns Universitet, NBI Report No. 52, Copenhagen, pp. 77, 1993.

Hasager, C. B., Carstensen, J., Frohn, L. M., Gustafson, B., Brandt, J., Conley, D., Geernaert, G., Henriksen, P., Ambelas Skjøth, C., and Johnsson, M.: 2003 MEAD retrospective analysis report, Ris $\varnothing$ Report. Ris-R-1385(EN), 92, Electronic format only http: //www.risoe.dk/rispubl/heavy.htm

Hertel, O., Christensen, J., Runge, E. H., Asman, W. A. H., Berkowicz, R., Hovmand, M. F., and Hov, Ø.: Development and Testing of a new Variable Scale Air Pollution Model - ACDEP. Atmospheric Environment, 29, 1267-1290, 1995.
Hertel, O., Ambelas Skjøth, C., Frohn, L. M., Vignati, E., Frydendall, J., de Leeuw, G., Schwarz, U., and Reis, S.: Assessment of the atmospheric nitrogen and sulphur inputs into the North Sea using a Lagrangian model, Physics and Chemistry of the Earth, 27, 1507-1515, 2002.

Joergensen, P. V.: Standard CZCS Case 1 algorithms in Danish Coastal waters. Int. J. Remote Sensing, 20(7), 1289-1301, 1999.

Joergensen, P. V.: SeaWiFS data analysis, and match-up's with insitu chlorophyll concentrations in Danish waters. Int. J. Remote Sensing, accepted 2003.

Johannessen, J. A., Johannessen, O. M., and Haugan, P. M.: Remote sensing and model simulation studies of the Norwegian coastal current during the algal bloom in May 1988. Int. J. Remote Sensing, 10, 10, 1893-1906, 1989.

Johnsson, M.: 2002 MEAD ScanFish data report, available at http: //www.oce.gu.se/downloads/scanfish_data_report.pdf

Kronvang, B., Ærtebjerg, G., Grant, R., Kristensen, P., Hovmand, M., and Kirkegaard, J.: Nationwide monitoring of nutrients and their ecological effects: state of the Danish aquatic environment. Ambio, 22, 176-187, 1993.

Kramer, H. J.: Observation of the Earth and its environment. Springer, NY, 3rd ed., pp. 960, 1996.

Mann, J., Kristensen, L., and Jensen, N. O.: Uncertainties of extreme winds, spectra, and coherences. In: Larsen and Esdahl (Eds.) Bridge Aerodynamics., A. A. Balkema, Rotterdam, 4956, 1998.

O'Reilly, J. E., Maritorena, S., Mitchell, B. G., Siegel, D. A., Carder, K. L., Garver, S. A., Kahru, M., and McClain, C.: Ocean color chlorophyll algorithms for SeaWiFS. J. Geophysical Research, 103, 24 937-24 953, 1998.

O'Reilly, J. E., Maritorena, S., Siegel, D., O’Brien, M. C., Toole, D., Mitchell, B. G., Kahru, M., Chavez, F. P., Strutton, P., Cota, G., Hooker, S. B., McClain, C. R., Carder, K. L., Muller-Karger, F., Harding, L., Magnuson, A., Phinney, G. F., Moore, D., Aiken, J., Arrigo, K. R., Letelier, R., and Culver, M.: Ocean color chlorophyll a algorithms for SeaWiFS, OC2, and OC4: version 4. In: S. B. Hooker and E. R. Firestone (Eds.), SeaWiFS Postlaunch Technical Report Series, vol. 11 SeaWiFS postlaunch calibration and validation analyses: part 3, NASA Goddard Space Flight Centre, Greenbelt, MD, 9-23, 2002.

Rasmussen, B. and Gustafsson, B. G.: Computation of Nutrient Pools and Fluxes at the entrance to the Baltic Sea, 1974-1999, Continental Shelf Research, in press, 2003.

Richardson, K.: Carbon flow in the water column case study: The southern Kattegat. In: B. B. Jørgensen and K. Richardson (Eds.), Coastal and estuarine studies, vol. 52, Eutrophication in coastal marine ecosystems, American Geophysical Union, Washington DC, 95-114, 1996.

Stewart, R. H.: Methods of satellite oceanography. Scripps Institution of Oceanography, San Diego, CA, pp.360, 1985.

Svejkovsky, J. and Shandley, J.: Detection of offshore plankton blooms with AVHRR and SAR imagery, Int. J. Remote Sensing, 22 (2), 471-485, 2001. 